which this training would be given at the Administrative Staff College.

Finally, the industrialist's point of view was put clearly and forcibly by Sir Ronald Weeks, deputy chairman of Vickers, Ltd., who defined the present obligations of both employer and employee. In his view the employer must regard himself as the trustee, be honest and fair in all his dealings, study the psychology of his employees, do everything possible to ensure good working conditions, know his own job and train his staff accordingly, pay an adequate wage for an honest day's work, endeavour to give his employees a sense of security and reasonable incentives for advancement, and finally, he must provoke a sense of loyalty and a 'sense of belonging'. The employee should observe obedience to rules and a sense of discipline, loyalty to the employer, and an honest day's work.

Sir Ronald emphasized Mr. Clay's belief that spontaneous co-operation cannot come without a sense of social purpose, and indicated that to-day the size of the pay packet on one side and the profit motive on the other are considered to be much more important than the conception of the universal and social purpose in industry. Sir Ronald then put forward various suggestions for the future improvement of industrial relations, indicating ways and means in which schemes of education and training for all grades could be introduced and implemented.

Altogether some 170 delegates attended the conference and, although they represented industries and public services having widely different problems and approached the discussion from widely different points of view, the conference was remarkable for the almost complete unanimity about the solutions that should be applied to Britain's economic crisis. Among the delegates were many representatives of firms who have been world pioneers in schemes of employee education and training and who have proved by experience that such schemes are eminently practical and beneficial. At this time of emergency their experience should not be ignored. T. H. HAwkINS

\section{HISTORY OF SCIENCE IN EDUCATION}

\footnotetext{
A JOINT meeting of the British Society for the History of Science with the Science Masters' Association, the Historical Association and the Association of Women Science Teachers was recently held at the Science Museum to discuss the subject "The Place of the History of Science in Education". The meeting was very well attended, and the chair was occupied by Dr. E. J. Holmyard, who took the opportunity of welcoming Prof. George Sarton as an honorary member of the British Society for the History of Science. The opening speakers were Dr. F. Sherwood Taylor, Mr. G. Fowles (a former chairman of the Science Masters' Association), Mr. S. M. Toyne (chairman of the Council of the Historical Association) and Miss L. E. Higson (secretary, Association of Women Science Teachers).

Dr. Sherwood Taylor said that he believed the principal aim of teaching science in the schools was to enable young people to make wise and sound decisions in their daily life. The teaching should also make clear how far, and in what regions, one may trust science. Instruction in the history of science could obviously provide a valuable means to this end.
}

There was too much tendency at the present day to teach factual rudiments only, and he would like to see more insistence upon scientific method. Where this involved a repetition of famous historical experiments, difficulties were bound to arise, since many of them did not lend themselves to the conditions of school curricula. There seemed to be a great opportunity for historical scientific films in this connexion, but such films must be of high accuracy or they would do more harm than good.

Mr. Fowles said that, in teaching science in schools,. the psychological factors were very difficult in that only about 5 per cent of the pupils could ever reach the standard represented by a university scholarship, and that the method of presentation had to be conditioned mainly by the needs of the remaining 95 per cent. So far as the historical method of teaching science was concerned, he thought there were three different aspects which he would describe as anecdotal, recapitulatory and evolutionary. Everybody was agreed that the anecdotal aspect was useful; but he doubted whether it was of value in explaining scientific method. The recapitulatory system was not altogether without defect, since pioneering work did not always provide the most direct or logical solution of the problem involved. General evolutionary consideration of scientific advance had more to recommend it, and this would be particularly valuable in teaching science to classical sixth forms. He agreed that some knowledge of the history of science was of great importance, but felt that it should form part of the general history course rather than of the science course.

Mr. Toyno described the methods he had adopted of teaching the history of science to boys on all sides in a public school. He felt that the history of science should form a part of the history course, but not at the expense of the history normally taught. $\mathrm{He}$ emphasized the fact that social history cannot pro. perly be explained without a knowledge of the history of science.

Miss Higson expressed the view that instruction in the history of science would be of advantage to all pupils in schools, especially those of sixth-form age. She had been distressed to find how little mention of men of science and scientific discovery was made in the standard histories used in the schools, and gave some examples. Apparently the only man of science to attract the attention of historians was Darwin. Miss Higson also remarked that she felt that science and its history should form an integral part of the 'current events' periods in schools, and agreed with Dr. Sherwood Taylor's plea for more science films.

Dr. Sarton said that in his opinion the value of the history of science was threefold. In the first place it was essential for science itself. Secondly, it formed an excellent introduction to philosophy. Thirdly, it had inherent cultural advantages, and these he would rate the highest. He gave an account of his own two-year course on the history of science at Harvard, in which he presented his students with a general survey of the developments of science and scientific thought from the earliest times to the present day, in four sessions of thirty-five lectures each.

The discussion then became general, and the con. sensus of opinion was that a very strong case had been made out for the inclusion of the history of science in the course for both schools and universities, and most speakers agreed that the teaching should form part of general historical study. 